\title{
NOTES ON INSECTIVOROUS COLEOPTERA.
}

By S. A. FORBES.

\section{Mouth Structures of Carabide.}

In studying the food of birds, I found it necessary to construct a key to the genera of the Carabidx, based primarily upon the mouth structures, and prepared for this purpose a large number of slides of the mouth parts of: Illinois species. In studying these, two characters were noted, which proved to be of considerable service for classification. The first of these is the frequent obliteration of the suture between the mentum and the gula (called the "gular suture", by Dr. LeConte, in his Classification, Pt. I, pp. X, XIII, 14, 15 and 16), the mentum being, in such cases, connate with the gula. This is true of Blechrus, although in Trechicus and Metabletus of the same group the suture is distinct. The mentum is again connate in many species, at least, of several genera of Dapti and Eurytrichi; viz., Geopinus, Anisodactylus, Xestonotus, Spongopus and Amphasia; but is not connate in Nothopus, Piosoma, Discoderes or Anisotarsus. This character was noticed nowhere else except in Amara angustata, which differs in this respect from all the other Amaræ in the Laboratory collection. This species is also peculiar in the very great development of the muscular ridges on the upper surface of the mentum. In the Lebiæ this mental suture is distinct in the middle but obsolete at the ends.

The second character referred to is found in the stipes of the maxilla. This body is covered with three platesan outer, closely connected with the palpus, a lower, from which the two lobes of the maxilla spring, and an upper plate, which is applied to the under surface of the mandible. The last of these usually presents, in the Harpalidæ, a more or less prominent angle at about the anterior third of the outer margin, although this margin is sometimes regularly curved. In two genera, Agonoderus and Sten- 
olophus, this plate is produced forward and outward beyond the articulation with the palpus (which thus seems to spring from beneath it), forming an oblique lamina with a rounded outer angle and an acute tip. This character seems to distinguish Stenolophus from Harpalus, as far as I have been able to compare the species.

\section{Food of the C'arabide.}

The large numbers of Carabidæ eaten by several of our common birds make it important that the somewhat doubtful food habits of this family should be more thoroughly studied; and I have undertaken the microscopic examination of the contents of stomachs and intestines as one branch of this investigation. The facts thus obtainable perhaps cannot give us a complete idea of the food of these insects, but should probably be taken in connection with field observations, as these beetles are said frequently only to suck the juices of their prey, rejecting the solid parts; and where this has been done the fact will be only obscurely indicated by the contents of the alimentary canal. Where this contained an abundance of fatty chyme with no solid tissues to fix its source, I have sometimes doubtfully inferred such an event; but usually liquid food will escape detection.

The results of the examinations thus far made are s? interesting that I am impelled to give the method I have found most successful and convenient, with the hope that others may turn their attention to the same subject. The dissection should be made as soon as possible after the beetle is taken-within a few days at farthest-as the more unstable elements of the food are apparently soon changed, even in strong alcohol. If the beetle is as large as Megilla maculata, the elytra and wings may be cut off and then, while the insect is held between the thumb and finger of the left hand, the edges of the abdomen mav be carefully trimmed away with a pair of fine scissors (those with curved blades are best) leaving the soft dorsal covering attached only at the base and tip. If one blade of the scissors be now earefully passed under this dorsal integument, it may be cut across and reflected (with the 
forceps and a mounted needle) forwards and backwards and cut entirely away. It will next be necessary to unroof the meso- and meta-thoracic segments, which usually contain at least a part of the crop. It will not be difficult to eut through the crusts of these segments at each side with the scissors-points. The terga may then be removed as before, with forceps and needle. The specimen (if not too large) should now be transferred to a watch crystal, covered with glycerine and placed on the stage of the microscope; (a dissecting microscope is a convenience, but not indispensable). With mounted needles the reproductive organs, urinary tubes, ete., can be pushed out of the way, when the crop, stomach and intestine will be seen, variously arranged according to the family and genus. It is an easy matter to cut the alimentary canal loose at either end and to remove it from the body, placing it upon a slide in a shallow cell, with glycerine enough to mount the contents. Here the superfluous structures should be picked away, as far as possible, and then the stomach and intestines may be torn open with needles, and their contents spread out and picked in pieces upon the slide. After the removal of the remnants, the cell may be covered and the contents studied with any power necessary. The cover should, of course, be finally cemented down and the slide preserved for verification and repeated examination.

Galerita janus.-A specimen of this insect, taken at Bloomington, in September, contained but little food. All that was recognized consisted of insect fragments, one of which was a spinose tibia. It was impossible even to tell the order of the insect eaten.

Loxopeza atriventris.-Four specimens of this species were examined, three of which were taken in June and the other in September. The alimentary canal of the first was entirely empty. The second, sent me by Mr. A. S. McBride, from DeKalb county, had eaten immense numbers of minute, oval bi-nucleate cells, which, believing them to be spores of fungi, I referred to Prof. T. J. Burrill, of the Illinois Industrial University. He reported them to be "spores of Sphæronemei, probably Phoma"- 
a fungus which forms small, black specks on dead wood, stems of weeds, etc. A third specimen from the same source had eaten some undetermined insect and about equal quantities of three elements; viz., the above spores of Phoma, pollen and the anthers of grass (doubtless blue-grass upon which the insect was taken). A few clavate bodies were also noticed, consisting of a single row of nucleated cells-evidently the acrospores of some fungus. A September specimen was taken at Normal. Its crop was distended with an oily liquid, but contained no other visible food except a few acrospores of a fungus. This specimen had evidently been feeding upon animal food of some sort.

Calathus gregarius.-Three individuals of this species were examined, all caught on blue-grass in blossom, by Mr. Webster, of Waterman, and Mr. McBride, of Freeland. The crop and œsophagus of the first were distended with a brown mass, which proved to be wholly made up of the pollen and fragments of the anthers of grass. A second specimen contained a smaller amount of pollen and anthers of blue-grass, with minute fragments of a black and sparsely hairy insect. An antenna proved that it was a larva-probably a young caterpillar. The third contained traces of a similar larva and the fragments of the cornea of a perfect insect-evidently a remnant of some former repast.

Anisodactylus baltimorensis.-The single specimen of this species had not recently taken food. The stomach was empty; but in the intestines was a large amount of chyme which possibly indicated liquid animal food. A specimen of $A$. rusticus gave only similar negative results.

Anisodactylus sericeus.-A specimen taken in June showed fragments of anthers and pollen of grass, with other vegetable tissues, apparently derived from the seeds of grass. A small insect had also been eaten, as shown by particles much too few and minute for determination. A second specimen had taken precisely similar food-the insect here being represented by a few facets of the cornea. 
Amara angustata.-One of this species, likewise taken in June, had also fed on vegetation, as indicated by a few particles of parenchyma too far digested for recognition; but fully nine-tenths of its food consisted of spherical eggs, in different stages of development, many of them easily recognizable as the eggs of mites. The most advanced embryos had six legs and a pair of large palpi; and, by the shape of the abdomen and the position of the legs, recalled the larvæ of the spinning mites (Tetranychi).

Harpalus pennsylvanicus DeG.-A specimen of this species taken running in the road, at Normal, August 31st had the alimentary canal well filled with vegetable tissues, some of which were evidently derived from the ovules and roots of grass. Among these were the tips of an ovule with the styles unbroken and the tip of a rootlet with the root-cap entire. A single mite was found, and a few acrospores of fungi. This beetles was infested by a large number of intestinal parasites of the genus Gregarina. A second specimen had eaten similar vegetable food. Here a piece of the epidermis of a rootlet, still covered with trichomes, was noted, as well as several roottips and fragments from the growing tips of grass. Pieces of the epidermis of grass with their peculiar zigzag cell boundaries, confirmed these determinations. A detached stigma of a grass floret and a few stylospores completed the food. A third specimen, taken at Normal on the 5th of September, contained some vegetable tissues with spiral cells, the mandible and maxilla of an ant and vast numbers of minute, spherical corpuscles, which Professor Burrill regarded as forms of bacteria such as occur on stagnant water. This beetle had apparently skimmed this minute vegetation from the surface of some pool. The fourth specimen of this species, received in September, from Mr. Webster, who collected it from the blossoms of ragweed, I found to have eaten large quantities of vegetable tissue, the fragments of which showed branched bundles of spiral ducts with parenchyma between. These were evidently the bracts or other floral organs of the ragweed. 
Harpalus caliginosus.-A single individual, running free upon the ground, had gorged itself with plant and animal food-apparently about three times as much of the former as of the latter. In the crop were a few hairs of a caterpillar and much half-digested muscle, with spores of fungi, a little epidermis of some graminaceous plant and a few pollen grains of Compositx. In the stomach was a great deal of chyme, with fragments of the wings and tarsi of some minute dipter, more pollen of Compositæ and some vegetable parenchyma, apparently derived from unripe seeds of grass. In the ileum and colon these last-mentioned tissues predominated, although the latter contained also a large quantity of pol. len of Compositæ indistinguishable from that of ragweed (Ambrosia). Here were also found two feet of a larvapossibly of the previously mentioned caterpillar. It is worthy of notice that these Harpali were full of eggs, of which there were about six in each abdomen. The crop of the second specimen, taken at Normal, in September, was distended with a brown, oily fluid, containing no recognizable material. In the intestine was a small mite and considerable vegetable parenchyma, apparently derived from some young seeds or ovules of plants. A little parallel-veined vegetable tissue was also seen, evidently derived from grass.

Harpalus herbivagus.-A specimen of this beetle, taken by Mr. McBride in July, was filled with cryptogamic vegetation which had the form of a dense mat of slender branching tubes enclosing many spherical cells. This, Professor Burrill, to whom one of the slides of this material was referred, regarded as a fleshy or cartilaginous fungus with Palmella cells, although he thought that it might have been derived from a lichen. A second specimen, obtained by Mr. Webster, in March, had evidently been feeding on the young shoots of grass.

Cratacanthus dubius.-One of this species, taken at Normal, in August, contained no apparent food except a few spores of fungi. In the stomach were great numbers of Gregarina, apparently of the same species as those found in Harpalus pennsylvanicus. In the colon, espe- 
cially, scores of these parasites in the "resting state" formed considerable masses which half filled the intestines.

Evarthrus colossus.-One of this species, taken in September, had eaten a brown beetle of medium size, the fragments of which filled the whole alimentary canal. From the general appearance of these, from the tips of one anterior and one middle tibia and from a maxillary palpus, it was inferred that this beetle was one of the Scarabæidæ. A fragment of a mandible showing a ridged masticatory surface, made it likely that it was a vegetable feeder. There was no trace of vegetable food in this Evarthrus. Another specimen, taken at Normal, in September, had eaten a large Coleopterous larva and two minute, indeterminable insects. Traces of confervoid Algæ were also discovered in the intestine.

Pterostichus sayi.-A specimen of this species, taken at Normal, in September, was full of the remains of an unrecognized hairy insect with two tarsal claws.

Pterostichus lucublandus.-This specimen, taken likewise at Normal, in September, contained a multitude of fragments of some Hymenopterous insect, including a maxillary palpus and a labrum nearly entire, with pieces of the legs and tarsi. This beetle had also eaten a small mite and a few acrospores of fungi.

Chlcnius tomentosus.-One of this species, taken at Normal, in September, contained traces of insect food not otherwise determined, and a nematoid parasite.

Chlanius diffinis.--A specimen of this species, taken under a log, near Normal, in September, contained traces of some crustaceous insect, with pieces of vegetable tissue (apparently wood) penetrated by the mycelium of a fungus. Large vegetable fragments were also seen, which Professor Burrill determined as pieces of a large, fleshy fungus. The stomach likewise contained acrospores of Dematiei.

Bradycellus dichrous.-A specimen, taken at Bloomington, in September, had eaten insect food not otherwise determinable. 
Twenty-eight specimens of Carabidæ, representing seventeen species, are here reported. It will be seen that twenty-one specimens, belonging to fifteen species, had eaten animal food, and that twenty specimens, belonging to eleven species, had eaten vegetation of some sort. I estimated as carefully as possible the relative amounts of these two kinds of food in the alimentary canal of each insect, and from these data concluded that about half the food of these twenty-eight specimens consisted of vegetation, and that one-third of it consisted certainly of insects-the remainder being made up of doubtful animal matter. About one-third of the vegetable food had been derived from cryptogamic plants and another from the different structures of grasses, Compositæ and other miscellaneous vegetation making up the remainder. C'onsidering the fact, however, that the commonest species were found feeding upon vegetation far the most generally, it is likely that, taking the Carabidæ as a group, not more than one-third or one-fourth of their average food consists of animal matter.

\section{Food of Podabrus.}

The contents of three stomachs of Podabrus tomentosus were examined; and all these had eaten only the spores of Phoma mentioned under Loxopeza. The specimens were all sent me in July, by Mr. A. S. McBride, of Freeland, Ill.

\section{Food of Coccinellide.}

Coccinella novem-notata.-Two specimens which were taken at Normal, in August, were examined, agreeing very closely in their food, each having eaten various spores of fungi (about ninety per cent.) and plant-lice (ten per cent.). Among the fungus spores, Professor Burrill, to whom they were submitted, recognized spores of Ustilago and Helminthosporium; and a few lichen spores were also noticed.

Brachyacantha ursina.-The stomach of one individual of this species contained only a few fungus spores.*

* I have assured myself that none of the fungi found in the alimentary canals of these beetles were entophytes. 
Hippodamia convergens.-A specimen, captured in August, at Normal, had eaten great quantities of fungus spores, which composed about three-fourths of its food. Fragments of a mite and a plant-louse and a little pollen of Compositæ were also found. In a second specimen, taken in September, the remains of a myriapod belonging to the family Geophilidx, acrospores of a fungus, the pollen of Compositx and the remains of a plant-louse were the only elements noticed.

Megilla maculata.-Three specimens of this species were dissected-one received from Mr. Webster in May, one from Mr. McBride in July, and one taken at Normal in September. The specimen from Mr. Webster was captured on the flowers of dandelions. Its entire alimentary canal was closely packed with hexagonal, spinose pollen cells, doubtless taken from that plant. A second had eaten the anthers and pollen of grass with a few spores of Myxogastres.* The third specimen contained pollen and fungus spores in about equal quantities. While these Coccinellidx had made good their usual reputation as enemies of plant-lice, it should be noticed that these constituted only about ten per cent. of their food.

If these specimens of the various families of predaceous beetles are fair examples of their class, the above facts imply that the individual carnivorous insect is much less valuable than has usually been supposed, while predaceous insects as a class are much more beneficial. If these species are predaceous, as a rule, not more than from one-fourth to one-third of the time, the injury done by the destruction of one of them is very much less than if they were, as is usually supposed, almost wholly carnivorous. But, on the other hand, if they can live on the soft parts of plants when animal food becomes scarce, their numbers will be maintained at a far higher figure than would be possible if they were dependent upon animal food alone. Preferring animal food to vegetable, as they doubtless do when equally obtainable, they operate as a much more effective check on the undue increase of other insects than if their number were at all times strict-

* Burrill. 
ly limited by the numbers of their food species. We should remember, in this connection, that we cannot ordinarily expect of any predaceous animal that it will do more than to eliminate the excess of the species it preys upon, keeping their numbers down within certain constant limits. As a prudent sovereign finds it worth while to maintain a much larger fighting force than is necessary to the ordinary administration of his government, in order that he may have always a reserve of power with which to meet aspiring rebellion, so it is to the general advantage that carnivorous insects should abound in larger numbers than could find sustenance in the ordinary surplus of insect reproduction. They will then be prepared to concentrate an overwhelming attack upon any group of insects which becomes suddenly superabundant. It is evidently impossible, however, that this reserve of predaceous species should be maintained unless they could be supported, at least in part, upon food derived from other sources than the bodies of living animals. 